\title{
Electricity sustainable energy management model for community development holistically in Phranakhon Rajabhat University
}

\author{
Isaree Srikun ${ }^{1, *}$ \\ ${ }^{1}$ Faculty of Industrial Technology, Phranakhon Rajabhat University, 10210 Bangkok, Thailand
}

\begin{abstract}
The research of electricity sustainable energy management model for holistic community development aims to (1) study the electric energy management and human behavior towards energy efficiency in Phranakhon Rajabhat University, (2) study the cooperation of relevant agencies and the role of community participants between Faculty of Industrial Technology, Phranakhon Rajabhat University and other organizations and (3) study benefits, problems, obstacles and suggestions in implementing the proposed energy management model in the pilot area. From the experimental results, it was found that the effective energy management requires several factors to achieve. Also, the collaborative model among relevant agencies, faculty, staff, students as community owners is essential to promote energy awareness among students and faculty staff.
\end{abstract}

\section{Introduction}

As The study of energy management has currently become a matter of great importance because of the significant increase of interest in energy sustainability, which has grown up continuously in Thailand. Considering constant problems arising from global warming and effects of carbon emissions from fuels, there is an increasing interest in energy conservation. Phranakhon Rajabhat University is one of the educational institutions that have historical significance to Bangkok. This university was Thailand's first teachers' training school located in the metropolis of Bangkok supporting the ever-growing constructions for sky train projects, residential and commercial buidings. The campus itself consists of many different buildings, with variety of use such as faculty offices, laboratories, classrooms, therefore it has faced rising cost of electricity and energy consumption every year. The continued growth in the campus demand for electrical energy and the university's need for an effective energy management model that will help offsetting the rising costs and increasing energy demand by focusing on reductions in energy consumption from faculty staff, students, executives and other people involved.

As a result, this research, taken place in Faculty of Industrial Technology, Phranakhon Rajabhat University, has proposed to study the energy management and human behavior towards energy efficiency on campus. The research also investigated into benefits,

\footnotetext{
* Corresponding author: isaree@pnru.ac.th
} 
problems, and suggestions in implementing the proposed energy management model in the Faculty of Technology building. In the paper are reported the energy management analysis from assessing human attitudes along with the university policies, and procedures that influence energy use in order to develop a suitable and sustainable energy management model for perpetuating energy savings and for incorporating energy efficiency into a wide range of university practices and procedures.

\section{Research Method}

In this study, questionnaire surveys on energy conservation behavior of 700 representatives of faculty staff and students were conducted to analyze energy consumption in Phranakhon Rajabhat University. An overview about the university energy management was investigated as fundamental information to analyze energy consumption on campus. Table 1 illustrated the current energy management matrix (EMM) according to several interviews with personnel in charge of the university's energy management.

Table 1. Current energy management matrix of Phranakhon Rajabhat University

\begin{tabular}{|c|c|c|c|c|c|c|}
\hline & Policy & Organizing & Training & $\begin{array}{l}\text { Performance } \\
\text { Measurement }\end{array}$ & Communicating & $\begin{array}{c}\text { Invest } \\
\text { ment }\end{array}$ \\
\hline (4) & $\begin{array}{c}\text { Energy } \\
\text { policy } \\
\text { action plan } \\
\text { and regular } \\
\text { review, } \\
\text { have active } \\
\text { commitme } \\
\text { nt from top }\end{array}$ & $\begin{array}{c}\text { Fully } \\
\text { integrated into } \\
\text { management } \\
\text { structure with } \\
\text { clear } \\
\text { accountability } \\
\text { for energy } \\
\text { consumption }\end{array}$ & $\begin{array}{l}\text { Appropriate } \\
\text { and } \\
\text { comprehensive } \\
\text { staff training } \\
\text { tailored to } \\
\text { identified } \\
\text { needs }\end{array}$ & $\begin{array}{l}\text { Comprehensive } \\
\text { performance } \\
\text { measurement } \\
\text { with effective } \\
\text { reporting }\end{array}$ & $\begin{array}{c}\text { Extensive } \\
\text { communication of } \\
\text { energy issues } \\
\text { within and outside } \\
\text { organization }\end{array}$ & $\begin{array}{l}\text { Resources } \\
\text { routine } \\
\text { committed } \\
\text { to energy } \\
\text { efficiency }\end{array}$ \\
\hline (3) & $\begin{array}{c}\text { Format } \\
\text { policy but } \\
\text { not active } \\
\text { commit- } \\
\text { ment from } \\
\text { top }\end{array}$ & $\begin{array}{l}\text { Clear line } \\
\text { management } \\
\text { and } \\
\text { responsibility } \\
\text { for } \\
\text { improvement }\end{array}$ & $\begin{array}{c}\text { Energy training } \\
\text { targeted at } \\
\text { major users } \\
\text { following } \\
\text { training need } \\
\text { analysis }\end{array}$ & $\begin{array}{l}\text { Weekly } \\
\text { performance } \\
\text { measurement } \\
\text { for each } \\
\text { building }\end{array}$ & $\begin{array}{l}\text { Regular staff } \\
\text { briefings, } \\
\text { performance } \\
\text { reporting and } \\
\text { energy promotion }\end{array}$ & $\begin{array}{c}\text { Some } \\
\text { appraisal } \\
\text { criteria } \\
\text { used for } \\
\text { cost } \\
\text { reduction } \\
\text { projects }\end{array}$ \\
\hline (2) & $\begin{array}{l}\text { Unadopted } \\
\text { policy }\end{array}$ & $\begin{array}{c}\text { Some } \\
\text { delegation of } \\
\text { responsibility } \\
\text { but line } \\
\text { management } \\
\text { and authority } \\
\text { unclear }\end{array}$ & $\begin{array}{l}\text { Ad-hoc internal } \\
\text { training for } \\
\text { selected people } \\
\text { as required }\end{array}$ & $\begin{array}{c}\text { Monthly } \\
\text { monitoring by } \\
\text { fuel types }\end{array}$ & $\begin{array}{l}\text { Some use of } \\
\text { company } \\
\text { communication } \\
\text { mechanisms to } \\
\text { promote energy } \\
\text { efficiency }\end{array}$ & $\begin{array}{l}\text { Low or } \\
\text { medium } \\
\text { cost } \\
\text { measures } \\
\text { considered } \\
\text { if short } \\
\text { payback } \\
\text { period }\end{array}$ \\
\hline (1) & $\begin{array}{l}\frac{\text { Unwritten }}{\text { set of }} \\
\text { guidelines }\end{array}$ & $\begin{array}{c}\frac{\text { Informal }}{\text { mainly }} \\
\text { focused on } \\
\text { energy supply }\end{array}$ & $\begin{array}{l}\text { Technical staff } \\
\text { occasionally } \\
\text { attend } \\
\text { specialist } \\
\text { courses }\end{array}$ & 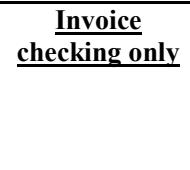 & $\begin{array}{c}\text { Ad-hoc informal } \\
\text { contacts used for } \\
\text { promoting energy } \\
\text { efficiency }\end{array}$ & $\frac{\frac{\text { Only low }}{\text { or no-cost }}}{\frac{\text { measures }}{\text { taken }}}$ \\
\hline$(0)$ & $\begin{array}{c}\text { No explicit } \\
\text { policy }\end{array}$ & $\begin{array}{l}\text { No delegation } \\
\text { of } \\
\text { responsibility } \\
\text { for managing } \\
\text { energy }\end{array}$ & $\frac{\frac{\text { No energy }}{\text { related staff }}}{\underline{\text { training }}}$ & $\begin{array}{c}\text { No } \\
\text { measurement of } \\
\text { energy costs of } \\
\text { consumption }\end{array}$ & $\begin{array}{c}\frac{\text { No }}{\text { communication }} \\
\frac{\text { or promotion for }}{\underline{\text { energy issues }}}\end{array}$ & $\begin{array}{c}\text { No } \\
\text { investment } \\
\text { for } \\
\text { improving } \\
\text { energy } \\
\text { efficiency }\end{array}$ \\
\hline
\end{tabular}

Total of 700 surveys from the Faculty of Industrial Technology representatives were carried out and analysis of energy consumption behaviors and attitudes in university campuses were based on four aspects, which were (1) energy management measure, (2) 
appliance repair and maintenance, (3) use of alternative/green energy and (4) energy conservation campaign and promotions. After that, several options of energy management model, practices and investment costs were primarily suggested and opened for public opinion, including university executives, faculty staff and students to develop social participation leading to a sustainable energy management model that can be extended to other peered institutions.

\section{Research Findings}

According to the questionnaires and public discussions, it was found that in terms of energy management measure aspect, the university representatives mostly need a systematic performance measurement of electrical energy for each building to raise more awareness on energy conservation. Whereas, for the appliance repair and maintenance aspect, public suggested that all electrical appliances and equipment should be inspected regularly for use. For the use of alternative or green energy aspect, it was found that people in the university prefer to have trees around the building to reduce heat following by the use of alternative energy such as solar cells to save energy. Finally, for energy conservation campaign and promotion aspect, public need an extensive promotion of energy efficiency following by the publication of energy saving information as a way to reduce power consumption.

Apart from public surveys and discussions, the research also analyzed investment costs and payback period for improving energy efficiency of air-conditioning and lighting systems under different energy management approaches using the Faculty of Industrial Technology building as a pilot area as shown in Table 2 .

Table 2 Investment costs for improving energy efficiency of air-conditioning and lighting systems

\begin{tabular}{|c|c|c|c|c|}
\hline \multirow{2}{*}{$\begin{array}{c}\text { Energy Management } \\
\text { Approach }\end{array}$} & \multicolumn{2}{|c|}{ Cost of savings } & \multirow{2}{*}{$\begin{array}{c}\text { Investment } \\
\text { Cost } \\
\text { (baht) }\end{array}$} & \multirow{2}{*}{$\begin{array}{c}\text { Payback period } \\
\text { (year) }\end{array}$} \\
\hline & kWh/year & baht/year & & \\
\hline \multicolumn{5}{|c|}{ Lighting System } \\
\hline $\begin{array}{c}\text { Housekeeping } \\
\text { (turn off lights during } \\
\text { lunchtime) }\end{array}$ & $4,873.04$ & $29,238.24$ & - & - \\
\hline $\begin{array}{l}\text { Process Improvement } \\
\text { (use of automatic light } \\
\text { control) }\end{array}$ & $5,256.18$ & $31,537.08$ & 52,200 & 1.66 \\
\hline $\begin{array}{l}\text { Process or Equipment } \\
\text { Change } \\
\text { (Use of LED lights) }\end{array}$ & $22,038.68$ & $132,232.1$ & 234,250 & 1.77 \\
\hline \multicolumn{5}{|c|}{ Air-conditioning System } \\
\hline $\begin{array}{c}\text { Housekeeping } \\
\text { (turn off air-conditioners } \\
\text { during lunchtime) } \\
\end{array}$ & 29,574 & 177,444 & - & - \\
\hline $\begin{array}{l}\text { Process Improvement } \\
\text { (Regular maintenance for } \\
\text { air-conditioners) }\end{array}$ & $16,561.4$ & $99,368.64$ & 69,600 & 0.7 \\
\hline $\begin{array}{l}\text { Process or Equipment } \\
\text { Change } \\
\text { (use of automatic control) }\end{array}$ & 59,148 & 354,888 & 217,500 & 0.61 \\
\hline
\end{tabular}




\section{Conclusions}

This research mentioned the findings of electricity sustainable energy management model for community development in Phranakhon Rajabhat University. From the surveys and discussion results, there must be several factors promoting the electric power management on campus. Also, understanding and awareness of university staff and students including positive attitudes and behaviors toward effective energy conservation are necessary for effective and sustainable energy management.

This research was supported by National Research Council of Thailand (NRCT). The author would like to thank colleagues from Phranakhon Rajabhat University who provided insight and expertise that greatly assisted the research, although they may not agree with all of the conclusions of this paper.

\section{References}

1. Dodooa, A. Gustavssona, L. andSathrea, R. Energy and Buildings, 43, 1589-1597 (2011)

2. Forbes, S. Values in Holistic Education, Third Annual Conference on Education, Spirituality and the Whole child. Roehampton Institute, (1996)

3. Forbes, S. What Holistic Education Claims About Itself; An Analysis of Holistic School's Literature. American Education Research Association, (2004)

4. Jina, Y. Wanga, L. Xiong. Energy and Buildings. 85, 155-164 (2014)

5. Osman, A. and Ries R. Int.J.LCA. 12 308-316 (2007)

6. Peschieraa, G. Taylor, J. Energy and Buildings, 49, 584-590 (2012)

7. Rastegar, M. and Fotuhi-Firuzabad M. International Journal of Electrical Power \& Energy Systems. 74 286-292 (2016)

8. US Green Building Council (USGBC). 2009. LEED-EBOM: Leadership in Energy and Environmental Design for Existing Buildings. Available from: www.usgbc.org (2013) 